\title{
Joanna SONDEL-CEDARMAS
}

Uniwersytet Jagielloński

E-mail: joanna.sondel@gmail.com

\section{GIOVANNI PREZIOSI I GENERALNY INSPEKTORAT DO SPRAW RASOWYCH (1944-1945)}

ABSTRACT Giovanni Preziosi and the General Inspectorate of Race (Ispettorato Generale Della Razza) (1944-1945)

This article is devoted to the analysis of the ideas of Giovanni Preziosi (1881-1945), an Italian journalist and director of the main anti-Semitic journal in Italy, "La Vita Italiana”, in circulation from 1921 to 1945 . He also served as Minister of State from 1942-1943, as well as the head of the General Inspectorate of Race in the period of the Italian Social Republic. He is regarded as one of the foremost theorists of Italian anti-Semitism in the XX century, as well as one of the main representatives of Fascism in the period preceding the March on Rome. Preziosi also played a leading role in the implementation of racist policies in Italy in the years 1938-1945. In his famous Memoriale, which he developed in January 1944 and then sent to Mussolini and Hitler, he blames Jews and Masons for the fall of Fascism on 25 July 1943 and proclaims the "final resolution of the Jewish problem" in Italy. As the head of the General Inspectorate of Race in the years 1944-1945, he attempted to adopt the German model in Italy, particularly in the project of bills he wrote in May 1944, which were based on the Nuremburg Laws from 1935 and which were to be a revision of the decrees from 1938-1939.

KEY WORDS nationalism, fascism, anti-Semitism, racist acts/ the Italia Social Republic

WVe współczesnej historiografii obowiązuje pogląd, że polityka rasistowska włoskiego faszyzmu, zainaugurowana Manifestem rasistowskim z 14 lipca 1938 r. i wprowadzona oficjalnie na mocy dekretu nr 1728 z dnia 17 listopada 1938 r. 
(tzw. Provvedimento per la difesa della razza), została przyjęta jako jedna z konsekwencji zacieśnienia relacji z hitlerowskimi Niemcami w $1936 \mathrm{r}^{1}{ }^{1}$ Niektórzy historycy są zdania, że ustawodawstwo rasistowskie zostało wręcz narzucone Włochom przez Hitlera². Tylko nieliczni zwracają uwagę, że już od początku lat 20. we Włoszech działali teoretycy antysemityzmu, którzy przygotowali pod względem ideologicznym grunt do wprowadzenia dekretów uderzających w Żydów³ ${ }^{3}$ a Włosi prowadzili politykę rasistowską w podległych im koloniach już w $1936 \mathrm{r}^{4}$

Zob.: M. Michaelis, On the Jewish Question in Fascist Italy. The Attitude of the Fascist Regime to the Jews in Italy, „Yad Vashem Studies” 1960, nr 4, s. 7-41; R. De Felice, Storia degli ebrei italiani sotto il fascismo, Torino 1961; I. Kirkpatrick, Mussolini. Study of a Demagogue, London 1964, s. 353; M.A. Ledeen, La "Questione ebraica” nell'Italia fascista, „Nuova Antologia” 1974, nr 109, s. 185-201; R. Pommerin, Le controversie di politica razziale nei rapporti dell'Asse Roma-Berlino (1938-1943), „Storia Contemporanea” 1979, nr 4-5, s. 925-940. Do zacieśnienia kontaktów z III Rzeszą (rozmowy Ciano-Ribbentrop z 23 października 1936 r.), które w rezultacie stały się dodatkowym impulsem przemawiającym za wprowadzeniem we Włoszech ustaw antysemickich, doprowadziły imperialistyczna polityka włoskiego faszyzmu i udział w hiszpańskiej wojnie domowej. W szczególności w wyniku wojny abisyńskiej na Włochy zostały nałożone sankcje ekonomiczne, które sprawiły, że Mussolini zbliżył się do Hitlera. Wspomniani historycy podkreślają jednak, że główną odpowiedzialność za wprowadzenie polityki rasowej we Włoszech ponosi sam Mussolini.

2 Taka interpretacja była szczególnie popularna na początku lat 40. Zob.: Pentad, The Remaking of Italy, London 1941, s. 103; E. Momigliano, Storia tragica e grottesca del razzismo fascista, Milano 1946, s. 48; P. Badoglio, L'Italia durante la seconda guerra mondiale, Milano 1946, s. 92.

3 Część historyków uważa, że antysemityzm był logiczną konsekwencją ideologii faszystowskiej, a nawet ważnym składnikiem życia społecznego Włoch w okresie przedfaszystowskim. Zob.: D. Cantimori, Prefazione, [w:] R. De Felice, Storia degli ebrei..., s. XXII; L. Salvatorelli, G. Mira, Storia d'Italia nel periodo fascista, Torino 1957, s. 753; G. Valabrega, Il fascismo e gli ebrei. Appunti per un consuntivo storiografico, [w:] Il fascismo e le autonomie locali, a cura di S. Fontana, Bologna 1973, s. 103; U. Caffaz, L'antisemitismo italiano sotto il fascismo, Firenze 1975, s. 2-3.

4 Politykę rasistowską w koloniach włoskich zaczęto stosować po podboju Etiopii w 1935 r. W pierwszym rzędzie wypowiedziano wojnę tzw. małżeństwom mieszanym. Na przełomie maja i czerwca 1936 r. zabroniono dzieciom pochodzącym z tego rodzaju związków posiadania obywatelstwa włoskiego, a na mocy ustawy z 9 stycznia 1937 r. zakazano konkubinatu pomiędzy Włochami a afrykańskimi poddanymi. Włoch, który dopuścił się biologicznego przestępstwa „skażenia rasy”, mógł zostać skazany na karę pozbawienia wolności od roku do lat pięciu. W 1939 i 1940 r. wyszły kolejne ustawy przeciwko Lesione del prestigio di razza (Szkodzeniu prestiżowi rasy), które przewidywały karanie również ludności tubylczej, i Meticci $(O$ mulatach), określająca status prawny dzieci z małżeństw mieszanych. W świetle tej ustawy rodzic włoski nie miał żadnej możliwości uznania dzieci z „mieszanego związku", które zostały pod względem prawnym zrównane z ludnością tubylczą. Zlikwidowano też wszelkie instytucje opiekujące się dziećmi „półkrwi”. Jedynie mulaci, którzy mieli więcej niż 12 lat, mogli wykazać się dobrą znajomością kultury włoskiej i ukończyli co najmniej trzy klasy szkoły podstawowej, niebudzący zastrzeżeń pod względem moralnym, cywilnym i politycznym, mogli otrzymać status obywateli włoskich. Zob.: S. Pyciński, Matżeństwa „mieszane" w faszystowskich Wtoszech (1938-1945), „Studia nad Faszyzmem i Zbrodniami Hitlerowskimi” (dalej: SnFiZH) 2002, t. 25, s. 244-245. Cytowany historyk podkreślił, że polityka rasowa prowadzona w Afryce nie odbiegała od prowadzonej przez inne kraje kolonialne. Sławomir Pyciński uważa też, że nie ma dowodów, iż antysemityzm został w jakikolwiek sposób narzucony Włochom przez nazistów. Był on raczej wyrazem cynizmu Mussoliniego, który postanowił wykorzystać ideologię antysemicką do własnych celów. Zob. także: A.M. Canepa, Half-hearted cynicism. Mussolini's racial politics, „Patterns of Prejudice” 1979, nr 13(6), s. $18-27$. 
Nie ulega wątpliwości, że stosunek faszyzmu do Żydów był dość złożony. Z jednej strony rząd Mussoliniego aż do 1938 r. wielokrotnie podkreślał, iż antysemityzm we Włoszech praktycznie nie istniał, a na pewno nie stanowił istotnego elementu doktryny faszystowskiej. Dla potwierdzenia tej tezy można przytoczyć artykuł Dina Monariego pt. Il miglioramento della razza e il Fascismo, który ukazał się na łamach faszystowskiego pisma „Gerarchia” w 1922 r. Jest rzeczą charakterystyczną, że chociaż traktował on o przedstawionych w Discorso all'Augusteo 7 listopada 1921 r. wytycznych Mussoliniego w kwestii polityki demograficznej zmierzającej do ulepszenia rasy, problem żydowski nie został w nim w ogóle podjęty . Podobnie aż do 1938 r. publicystyka faszystowska nie poświęcała zbyt wiele uwagi kwestii żydowskiej, a sam Mussolini w rozmowie z Emilem Ludwigiem wiosną 1932 r. stwierdził: nie ma już czystych ras, gdyż nawet $\dot{Z} y d z i$ nie uniknęli pomieszania. Szczęśliwe pomieszanie ras stawato się wtaśnie nieraz przyczyna sity i piękna narodów. Na rasę sktada się raczej uczucie niż realna rzeczywistość; uczucie stanowi w niej dobre 95 procent. Nie wierze w to, aby można byto udowodnić biologicznie, $\dot{z}$ e dana rasa jest bardziej lub mniej czysta ${ }^{6}$. Duce podkreślił także oddanie i odwagę cywilną włoskich Żydów jako obywateli, ich niekwestionowane bohaterstwo na froncie I wojny światowej oraz istotną rolę, jaką odgrywali w życiu państwa ${ }^{7}$. Faktem jest, że Żydzi w momencie dojścia faszyzmu do władzy pod względem ilościowym stanowili zdecydowaną mniejszość (na początku lat 20. Półwysep Apeniński zamieszkiwało okoto 50 tys. Żydów), byli dobrze zintegrowani i w znakomitej większości dobrze wykształceni. Wielu z nich jeszcze przed Marszem na Rzym poparło ruch Mussoliniego, a następnie zajmowało odpowiedzialne stanowiska w faszystowskiej partii i w administracji państwowej (jak na przykład Guido Jung - minister finansów w latach 1932-1935, Gino Arias - wybitny ekonomista i historyk prawa, Carlo Foà - endokrynolog i fizjolog odznaczony m.in. medalem Accademia Nazionale dei Lincei, Margherita Grassini Sarfatti - znana pisarka i biografka Mussoliniego, czy Angelo Oliviero Olivetti - jeden $\mathrm{z}$ teoretyków faszystowskiego syndykalizmu i korporacjonizmu) $)^{8}$.

Niezależnie jednak od tych publicznych deklaracji Mussoliniego w 1938 r. faszystowski rząd wprowadził ustawy o charakterze antysemickim.

Włoski historyk, dyrektor Centro di Documentazione Ebraica Contemporanea w Mediolanie, Michele Sarfatti podzielił politykę rasistowską włoskiego faszyzmu na dwa okresy: 1) od lipca 1938 r. do lipca 1943 r., kiedy faszystowski reżim próbował wyeliminować Żydów z życia społecznego i narodowego Włoch, historyk nazywał ten

Zob. D. Monari, Il miglioramento della razza e il Fascismo, „Gerarchia” 1922, nr 9, s. 592-596.

6 Słowa wypowiedziane wiosną 1932 r. w rozmowie z Emilem Ludwigiem. Zob.: E. Ludwig, Colloqui con Mussolini, trad. T. Gnoli, Milano 1932, s. 73-74. Mussolini dołączył też swą wypowiedź określającą rasę jako kwestię uczucia, nie zaś rzeczywistości, do La Dottrina del Fascismo z 1932 r. Zob.: W. Kozub-Ciembroniewicz, Żydzi w doktrynie wtoskiego faszyzmu na tle Manifesto degli scienziati razzisti z 14 lipca 1938 r., SnFiZH 1992, t. 15, s. 36.

7 Zob.: W. Kozub-Ciembroniewicz, Żydzi w doktrynie wtoskiego faszyzmu.., s. 36.

8 Jak podaje Michele Sarfatti, w 1938 r. ok. 6900 Żydów było zapisanych do Narodowej Partii Faszystowskiej. Zob. M. Sarfatti, La Shoah in Italia. La persecuzione degli ebrei sotto il fascismo, Torino 2005, s. 70 . 
etap okresem prześladowania praw, i 2) od 8 września 1943 r. do 25 kwietnia 1945 r., kiedy przystąpiono do realizacji we Włoszech postanowień konferencji w Wannsee z 20 stycznia 1942 r. - etap ten Sarfatti określit jako okres prześladowania życia9

W pierwszym ze wspomnianych okresów głównym celem polityki rasistowskiej miało być wykluczenie Żydów poza obręb włoskiej, aryjskiej wspólnoty narodowej. Generalnie polityka ta opierała się na następujących rozporządzeniach i dokumentach programowych:

1) Manifeście rasistowskim z 14 lipca 1938 r., wprowadzającym kryterium biologiczne oraz tezę o istnieniu czystej (aryjskiej) rasy włoskiej przy jednoczesnym uznaniu Żydów za ludność, która nie ulegta asymilacji, będąc skonstruowana z nieeuropejskich elementów rasowych ${ }^{10}$.

2) Rozporządzeniu mającemu na celu dyskryminację przybyłych z innych krajów Żydów, którym zabroniono uczęszczać do włoskich szkół (3 sierpnia 1938 r.), i wprowadzeniu numerus clausus dla uczestnictwa Żydów w życiu publicznym (5 sierpień $1938 \mathrm{r}$.).

3) Uchwale Wielkiej Rady Faszystowskiej z 6/7 września 1938 r., wprowadzającej „Kartę Rasową” („Carta della Razza”) w kwestii segregacji ras, która definiowała rasę żydowską (osoby z obojga rodziców Żydów, mające żydowskiego ojca i matkę cudzoziemkę oraz pochodzące z małżeństwa mieszanego, które od 1 października 1938 r. wyznawały judaizm), wprowadzała zakaz związków pomiędzy Włochami a semitami oraz innymi rasami niearyjskimi, a także dopuszczała ograniczenia w kwestii obywatelstwa (przewidywała ona nawet wypędzenie cudzoziemskich Żydów oraz pozbawienie obywatelstwa włoskiego Żydów osiedlonych we Włoszech po 1919 r.). Idąc dalej, zakładała ona także wykluczenie Żydów (poza nielicznymi wyjątkami ${ }^{11}$ ) z partii faszystowskiej oraz wprowadzała zakaz posiadania ziemi (więcej niż 50 ha), kierowania firmą (zatrudniającą ponad 100 osób) i ograniczała aktywność zawodową Żydów, w szczególności w dziedzinie szkolnictwa. Jak podkreślił jednak Sławomir Pyciński, od tego rozporządzenia istniało szereg wyjątków, np. zezwolenie na kontynuację badań przez naukowców oraz dokończenie studiów, co wyraźnie odróżniało Włochów od nazistów ${ }^{12}$.

9 Tamże, s. 75. Jak wykazal jednak krakowski politolog Wiesław Kozub-Ciembroniewicz, faszystowski antysemityzm i rasizm stanowiły raczej złagodzoną formę hitlerowskiego wzorca. W szczególności dekrety włoskie z 1938 i 1939 r. zdecydowanie różnily się od ustawodawstwa rasistowskiego III Rzeszy z lat 1935-1938. Zob. W. Kozub-Ciembroniewicz, Żydzi w doktrynie..., s. 39.

10 Tamże.

11 Nie miała być prowadzona dyskryminacja Żydów obywatelstwa włoskiego, którzy byli: 1) ochotnikami w czasie wojny światowej, libijskiej, etiopskiej czy hiszpańskiej, 2) weteranami ruchu faszystowskiego z lat 1919-1922 lub wstąpili do ruchu w drugiej połowie 1924 r. (po zabójstwie Giacomo Matteottiego), 3) członkami Legionu Fiume D’Annunzia, 4) osobami o nadzwyczajnych zasługach, co miała zweryfikować specjalna komisja. Zob.: S. Pyciński, Matżeństwa „mieszane” w faszystowskich Wtoszech..., s. 249-250.

12 Wprowadzono zakaz prowadzenia zajęć w szkołach publicznych, wykonywania zawodu nauczycielskiego, wykluczenie z uniwersytetów oraz członkostwa w akademiach, instytutach, stowarzyszeniach 
4) Uchwale Wielkiej Rady Faszystowskiej oraz dekrecie z 17 listopada 1938 r. O ochronie rasy wtoskiej (Provvedimenti per la difesa della razza italiana), wprowadzającym zakaz mieszanych małżeństw i inne ograniczenia dotyczące obywateli włoskich rasy żydowskiej, m.in. w zakresie stosunków własnościowych i publicznych ${ }^{13}$.

5) Kolejnych zakazach wprowadzonych od lutego do sierpnia 1939 r., które przewidywały dalsze ograniczenia w wykonywaniu niektórych zawodów, a także w kwestii przynależności do Narodowej Partii Faszystowskiej (PNF) ${ }^{14}$.

Od r. 1938 do 25 lipca 1943 r. polityką antyżydowską we Włoszech kierowało kilka instytucji: Naczelna Dyrekcja do spraw Demografii i Rasy (Direzione generale per la demografia e la razza, tzw. „Demorazza”) przy Ministerstwie Spraw Wewnętrznych, która zajmowała się przede wszystkim kwestiami normatywnymi, Instytut Propagandy i Studiów nad Problemami Rasowymi (Ufficio propaganda e studi sulla razza, zwany „Ufficio razza”) przy Ministerstwie Kultury Ludowej, Przedsiębiorstwo Zarządzania i Likwidacji Nieruchomości (Ente di gestione e liquidazione immobiliare - „Egeli”) oraz Naczelna Dyrekcja Bezpieczeństwa Publicznego (Direzione generale della pubblica sicurezza) przy Ministerstwie Spraw Wewnętrznych. Po 8 września 1943 r. wszystkie wspomniane urzędy wznowiły swoje działanie.

W okresie istnienia Włoskiej Republiki Społecznej (Repubblica Sociale Italiana RSI, zwanej także „Republiką Salò”), utworzonej 25 września 1943 r. w centralno-północnych Włoszech pod protektoratem Trzeciej Rzeszy, polityka represji wobec Żydów uległa zaostrzeniu. Należy zaznaczyć, że była ona wynikiem współpracy faszystów republikanów i Głównego Urzędu Bezpieczeństwa Rzeszy (Reissicherheitshauptamt RSHA). Organizacją prześladowania włoskich Żydów zajęły się już pod koniec września 1943 r. komórki niemieckiej policji bezpieczeństwa i partyjnej służby bezpieczeństwa (Sicherheitsdienst - SD), podlegające SS Gruppenführerowi Wilhelmowi Harsterowi, a ogólne wytyczne w kwestii zaostrzenia polityki rasistowskiej przyjęto na pierwszym Kongresie Republikańskiej Partii Faszystowskiej w Weronie w dniach 14-16 listopada 1943 r. Na mocy artykułu 7 Manifestu Werońskiego (tzw. Carta di Verona) przynależacych do rasy żydowskiej uznano za cudzoziemców i traktowano jako narodowość wrogq w czasie trwającej wojny. W dniu 30 listopada 1943 r. minister spraw wewnętrznych Guido Buffarini Guidi wydał rozkaz zaaresztowania Żydów zamieszkujących obszar Republiki Salò, nakazując jednocześnie konfiskatę ich mienia ${ }^{15}$.

naukowych, a także z prac nad podręcznikami szkolnymi. Jednocześnie też zakazano przyjmować nowych uczniów i studentów żydowskiego pochodzenia na kursy i studia. Tamże, s. 248.

13 Zob.: W. Kozub-Ciembroniewicz, Manifest rasistowski, [w:] Doktryny wtoskiego faszyzmu i antyfaszyzmu w latach 1922-1939, Kraków 1992, s. 89, Zeszyty Naukowe Uniwersytetu Jagiellońskiego, 1068, Prace $z$ Nauk Politycznych, z. 45.

14 Szerzej na ten temat zob.: H. Heiber, Die deutsche Einflussung der Rassenpolitik des fasistischen Italien bis 1938, [w:] P. Kluke, Gutachten des Instituts für Zeitgeschichte, t. 2, Stuttgart 1966, s. 86.

15 Na mocy rozporządzenia nr 5 z 30 listopada 1943 r. Żydzi mieli być osadzeni w obozach internowania podlegających perfektom. Początkowo wykorzystywano do tych celów stare wille, koszary, opuszczone fabryki, klasztory, hotele. Następnie w różnych prowincjach przystąpiono do tworzenia obozów 
Zalecił także obserwację osób wywodzących się z małżeństw mieszanych, które na mocy wcześniejszych rozporządzeń z 1938 r. posiadały status Aryjczyków. Następnie dekretem z 4 stycznia 1944 r. w kwestii Nowych dyspozycji w sprawie majątku obywateli żydowskich zabroniono Żydom posiadania akcji, polis ubezpieczeniowych i gruntów oraz nakazano konfiskatę ich majątków (w tym rzeczy codziennego użytku), a w dniu 28 stycznia nakazano rozwiązać istniejące gminy żydowskie i zarekwirować należące do nich dzieła sztuki i przedmioty kultu. Już w dniu 23 września 1943 r. dowództwo RSHA ogłosiło, że Żydzi narodowości włoskiej nie będą zwolnieni od deportacji do obozów koncentracyjnych, zaś całą akcją miał kierować komisarz ds. Żydów Theodor Dannecker (do grudnia 1943 r.), a następnie, od stycznia 1944 r. - Friedrich Bosshamer.

Władzom Włoskiej Republiki Społecznej udało się nieco złagodzić niektóre rozporządzenia niemieckie. W dniu 10 grudnia 1943 r. szef policji RSI Tullio Tamburlini określił wyjątki od internowania, które miały dotyczyć następujących kategorii: starców, chorych oraz tzw. „zaryzowanych”, tzn. pozostających w związkach małżeńskich z Aryjczykami. 20 stycznia 1944 r. Buffarini Guidi zaprotestował przeciwko „nielegalnym” niemieckim deportacjom Żydów włoskich na Wschód ${ }^{16}$, a 19 marca zwrócił się z apelem do prefektów, żeby nie pozbawiali Żydów wszystkich potrzebnych im środków do życia i tym samym nie stosowali się do wydanych wcześniej rozporządzeń dotyczących całkowitej konfiskaty żydowskiego mienia ${ }^{17}$. Włoska historyk Liliana Picciotto oszacowała, że w latach 1943-1945 wywieziono około 6806 Żydów (z czego powróciło jedynie 837), 322 zginęło na terytorium Włoch, a pełny bilans włoskich ofiar Shoa wynosi $8529^{18}$. Nie ulega wątpliwości, że zaostrzenie polityki represji wobec Żydów w okresie istnienia RSI było w dużej mierze spowodowane działalnością Giovanniego Preziosiego - generalnego inspektora do spraw rasowych, który w odniesieniu do tej kwestii próbował przenieść na grunt włoski wzorce niemieckie.

internowania. Najważniejszymi obozami na terytorium północno-centralnych Włoch były: Fossoli di Carpi koło Modeny, Borgo San Dalmazzo (Cuneo) oraz Gries w Bolzano. Odmienny charakter miał obóz La Risiera di San Sabba, znajdujący się na terytorium Adriatische Küstenland, powstały na przełomie października i listopada 1943 r., którym kierował Höherer SS und Polizeiführer Odilo Globocnik. Jest uważany za jedyny prawdziwy obóz koncentracyjny we Włoszech i określony mianem „Polizei-Haftlager”. W styczniu 1944 r. również obóz w Fossoli przeszedł pod zarząd Niemców, stając się tzw. obozem „Polizei - und Durchgangslager”.

16 Żydów włoskich przewożono do hitlerowskich obozów zagłady, w szczególności do KL Auschwitz, Berden Belsen, Buchenwald, Ravensbrück, Flossenburg, Mauthausen i Dachau.

17 Zob.: R. De Felice, Storia degli ebrei..., s. 434-438.

18 W liczbie wszystkich włoskich ofiar uwzględnia się również ok. 1820 Żydów z greckich wysp Dodekanezu, które znajdowały się pod okupacją Włoch. Należy także zaznaczyć, że podawane cyfry wraz z postępem badań nad deportacją włoskich Żydów do niemieckich obozów zagłady ulegają modyfikacji. Zob.: L. Picciotto, La macchina antiebraica della RSI e l'Ispettorato generale per la razza. Giovanni Preziosi, [w:] La Repubblica Sociale Italiana a Desenzano. Giovanni Preziosi e l'Ispettorato Generale per la razza, a cura di M. Sarfatti, Firenze 2008, s. 31. 


\section{GIOVANNI PREZIOSI - KARIERA ANTYSEMITY}

Giovanni Preziosi (1881-1945) - włoski dziennikarz, znany przede wszystkim dzięki przeprowadzonej w latach 1938-1945 kampanii antysemickiej ${ }^{19}$, autor włoskiej wersji Protokotów mędrców Syjonu, która ukazała się na łamach kierowanego przez niego pisma „La Vita Italiana” w 1921 r. $^{20}$, a zarazem jeden z czołowych przedstawicieli faszyzmu w okresie poprzedzającym Marsz na Rzym. Urodził się w 1881 r. w Torella dei Lombardi, zmarł 26 kwietnia 1945 r. w Mediolanie. Ukończywszy teologię w Almo Collegio dei Teologi w Neapolu, w młodości związał się z modernistycznym ruchem chrześcijańsko-demokratycznym Giovanniego Semeria i Romola Murri, powstałym w Rzymie w 1900 r. w celu stworzenia masowej partii katolickiej z inspiracji demokratycznej. Ostatecznie w 1913 r. porzucił kapłaństwo, co spowodowało obłożenie go ekskomuniką papieską. W 1904 r. podją badania nad kwestią zacofanego południa Włoch (tzw. Questione Meridionale), czemu dał wyraz w artykułach publikowanych na łamach katolickiego dziennika „La Patria”. Jednocześnie też zainteresował się problemem emigracji z południowych regionów Półwyspu Apenińskiego. W latach 1904-1909 współpracował z „Opera di assistenza per gli emigrati italiani in Europa e nel Levante” (bardziej znaną jako „Opera Bonomelli”), która powstała w 1904 r. z inicjatywy biskupa Cremony Geremia Bonomelli. Jako misjonarz odbył wiele podróży, w szczególności do Ameryki Północnej, gdzie badał warunki życia włoskich emigrantów. W artykułach zebranych następnie w studium pt. Gli Italiani negli Stati Uniti del Nord dostrzegał problem zagrożenia utraty tożsamości włoskiej u emigrantów oraz podkreślał potrzebę utrzymywania więzi z ojczyzna, ochrony wtoskiego jezyka $i$ kultury i stworzenia organizacji kulturalnych, które miały pomóc emigrantom w integracji w nowych ojczyznach. Należy zaznaczyć, że problem włoskiej emigracji w pierwszym dziesięcioleciu XX w. szczególnie leżał na sercu włoskim nacjonalistom. Jak jednak wykazała włoska historyk i autorka biografii Preziosiego Maria Teresa Pichetto, wpływ na jego idee w tym okresie miały głównie koncepcje socjalistów. Po powrocie do Włoch w 1912 r. związał się on z Gaetanem Salveminim i socjalistycznymi czasopismami „L'Unità” oraz „La Calabria del Popolo". Z socjalistycznym politykiem łączył go nie tylko problem emigracji, ale także krytyka prowadzonej przez rząd Giovanniego Giolittiego polityki protekcjonistycznej, kampania za wprowadzeniem powszechnego prawa głosu oraz potrzeba

19 Jak sam podkreślił w swoim sztandarowym studium pt. Giudaismo, bolscevismo, plutocrazia, massoneria z 1941 r., był dla Żydów, krypto-Żydów, zwolenników Żydów i masonów twórcą antysemityzmu politycznego we Wtoszech.Zob.: G. Preziosi, Giudaismo, bolscevismo, plutocrazia, massoneria, Milano 1943, s. 24.

20 W 1920 r. Preziosi przetłumaczył Protocolli dei Savi anziani di Sion z wersji francuskiej Ernesta Jouina, dyrektora „Revue internationale des sociétés secrètes”. W okresie faszyzmu Protokoty w tłumaczeniu Preziosiego miały dziewięć wydań: w 1937, 1938, 1939, 1941, 1944 i 1945 r. Wersja z września 1937 r. została opatrzona krótkim komentarzem Preziosiego datowanym na 15 września 1937 r. i poprzedzona dłuższym wstępem Juliusa Evoli. Wraz z pierwszą edycją w opracowaniu Preziosiego I Protocolli ukazały się też w innym tłumaczeniu jako dodatek do pisma „Fede e Ragione”, kierowanego przez księdza Umberta Benigniego od 27 marca do 12 czerwca 1921 r. 
przeprowadzenia gruntownej reformy politycznej. W celu oddziałania na rząd włoski i uwrażliwienia go na problemy emigrantów założył w styczniu 1913 r. miesięcznik „La Vita Italiana all'Estero” (z podtytułem „pismo emigracji politycznej”), który następnie w 1915 r. przekształcił się w „La Vita Italiana” i pod nowym tytułem ukazywał się nieprzerwanie aż do $1943 \mathrm{r}$.

Począwszy od 1914 r., Preziosi związał się bliżej z ugrupowaniem nacjonalistycznym, podzielając jego koncepcje irredentystyczne, interwentystyczne, antydemokratyczne i antysocjalistyczne polączone z krytyką polityki Giolittiego. W tym samym roku na łamach „La Vita Italiana all'Estero” opublikował wyniki referendum przeprowadzonego wśród deputowanych w parlamencie austriackim w kwestii stosunku do włoskich poddanych zamieszkujących terytorium Monarchii Austro-Węgierskiej. Poprowadził także ostrą kampanię propagandową przeciwko funkcjonowaniu obcych, przede wszystkim niemieckich, udziałowców w radzie administracyjnej Banca Commerciale. Artykuły poświęcone niebezpieczeństwu związanemu z przenikaniem obcych kapitałów na rynek włoski zostały następnie zebrane w studium pt. La Germania alla conquista dell'Italia z $1915 \mathrm{r}^{21}$ Preziosi starał się w nim wykazać, że owa infiltracja odbywała się w formie utajonej i nie była w żaden sposób blokowana przez kolejne liberalne rządy. W celu zwalczania tego utajonego wroga, który przeniknął do każdego sektora państwowego wraz z grupą interwentystów rzymskich, założył w czerwcu 1916 r. tygodnik „Fronte Interno”, a następnie w dniach 9-10 grudnia 1917 r. wraz z Maffeo Pantaleonim, Antoniem Salandrą, Luigim Federzonim i Enrikiem Corradinim utworzył związek przeciwników zawarcia ugodowego pokoju po klęsce pod Caporetto pod nazwą „Fascio parlamentare di difesa nazionale”.

24 maja 1918 r. wraz z Pantaleonim stworzył z kolei „Fascio nazionale italiano”, stawiające sobie za główny cel walkę z przeciwnikami toczącego się konfliktu zbrojnego, którzy powinni być traktowani jak wrogowie państwa, i przeciwstawianie się działalności Izby Deputowanych, która zamienita się w trybune przeciwników wojny podczas gdy ojczyzna wojne prowadzita 22 .

\section{PREZIOSI A FASZYZM}

Od samego początku powstania Fasci di combattimento Preziosi był zdecydowanym zwolennikiem faszyzmu, który uważał za ruch reakcyjny, zdolny stłumić pojawiające się we Włoszech po I wojnie światowej tendencje bolszewickie i wykorzenić lewicowe organizacje oraz związki zawodowe. Ostatecznie przyłączył się do ruchu faszystowskiego 1 maja 1920 r. Był przekonany, że tylko ruch masowy, jakim był faszyzm, a nie elitarny nacjonalizm, mógł stawić czoła wzrastającej na znaczeniu partii socjalistycz-

21 Wstęp opracował ekonomista, jeden z głównych przedstawicieli Stowarzyszenia Nacjonalistów Włoskich, M. Pantaleoni oraz G.A. Colonna di Cesarò, dyrektor pisma „Rassegna contemporanea”. Zob.: G. Preziosi, La Germania alla conquista dell'Italia, Firenze 1915.

22 Zob.: R. De Felice, Mussolini il rivoluzionario, Torino 2005, s. 440, przyp. 1. 
nej i następnie (od 1921 r.) komunistycznej oraz stworzyć podstawy silnego państwa. Dostrzegając powszechne zagrożenie bolszewizmem we Włoszech, od 1921 r. prowadził kampanię prasową przeciwko działalności lewicowych spółdzielni zawodowych. Na przełomie września i października 1922 r. został członkiem dyrekcji Narodowej Partii Faszystowskiej i jednym z głównych organizatorów Marszu na Rzym. Szczególnie prężnie działał w neapolitańskiej komórce partii, a na Kongresie PNF w Neapolu w dniach 7 i 24 października 1922 r. wygłosił referat poświęcony kwestii zacofanego Południa Włoch (Questione Meridionale). Od 1925 r. związał się z radykalnym odłamem faszyzmu pod przywództwem Roberta Farinacciego. Był jednocześnie przeciwnikiem bardziej umiarkowanego skrzydła, reprezentowanego przez byłych nacjonalistów, skupionych wokół Luigiego Federzoniego. Poparł jednak kampanię antymasońską nacjonalistów, która doprowadziła do przyjęcia przez Wielką Radę Faszystowską w dniu 13 lutego 1923 r. projektu ustawy o niemożliwości pogodzenia przynależności partyjnej i członkostwa w masonerii. W 1922 r. na lamach „La Vita Italiana” w artykule pt. Alla scoperta della massoneria opublikował nazwiska i stopień wtajemniczenia „dygnitarzy" PNF wpisanych do masonerii wraz ze spisem wszystkich lóż masońskich istniejących i działających we Włoszech oraz w koloniach, a także statystykę Żydów zatrudnionych w administracji państwowej.

Jednocześnie też na początku lat 20. rozpoczął kampanię antyżydowską, czego wyrazem była opracowana przez niego krytyczna wersja sztandarowego dzieła światowej propagandy antysemickiej - Protokoty mędrców Syjonu, która ukazała się w 1921 r. Publikując natomiast w sierpniu 1922 r. pierwsze wyniki badań na temat liczby Żydów $\mathrm{w}$ administracji państwa, uzasadniał, że stanowią oni osobne państwo w państwie. Duża liczebność Żydów w wojsku, szkolnictwie, dziennikarstwie stanowiła jego zdaniem potwierdzenie reguły przedstawionej w Protokotach, że Żydzi próbują podporządkować sobie poszczególne kraje, przejmując kontrolę nad kluczowymi gałęziami życia gospodarczego, politycznego i społecznego. Zamierzał w ten sposób wykazać, że faszyzm po Marszu na Rzym był zmuszony sprawować rządy w oparciu o biurokrację, będącą w rzeczywistości na usługach judaizmu i masonerii. Krytycznie ocenił postanowienie Wielkiej Rady Faszystowskiej o „niedopuszczalności” łączenia stanowisk partyjnych z przynależnością do masonerii, uznając je za ugodowe, gdyż jak uzasadniał, cztonkowie lóż masońskich pozostanq $w$ ukryciu masonami, pomagając sobie nawzajem $w$ celu utrzymania wtadzy, utrzymując kontakty $z$ międzynarodowymi komórkami masonerii i tworzac „coś w rodzaju gęstej sieci, przez którą nie przedostaną się nie zwiąani z żydo- masoneria ${ }^{\prime 23}$. Podobnie w czasie dyskusji nad reformą administracji publicznej w dniu 16 marca 1923 r. opowiedział się za pełnym wyeliminowaniem masonów z biurokracji i wojska. Ustawa przyjęta przez Wielką Radę PNF była jednak zdaniem Preziosiego skazana na przegraną, ponieważ jej wykonanie powierzono Giacomowi Acerbie i Pietrowi Badogliemu, będącym w przeszłości członkami loży masońskiej. Przy okazji kolejnego zakazu przynależności do masonerii w sierpniu 1924 r. i przyjęcia ustaw antyma-

23 Zob.: I Protocolli dei Savi Anziani di Sion, con introduzione e appendice di G. Preziosi, Milano 1944, s. 32 . 
sońskich w 1925 r. Preziosi kontynuował swoją kampanię przeciwko koalicji żydowsko-masońsko-plutokracyjnej na łamach kierowanych przez siebie pism, neapolitańskiego „Mezzogiorno” (w latach 1923-1929) oraz „Roma” (od 1927 r.).

To radykalne stanowisko przyniosło Preziosiemu więcej szkód niż pożytku. Prowadzona $\mathrm{z}$ wielką gorliwością wraz z eks-masonem Roberto Farinaccim walka z rzekomymi infiltracjami judejsko-masońskimi w partii faszystowskiej doprowadziła do wykluczenia go z listy kandydatów do Izby Deputowanych w wyborach w kwietniu $1924 \mathrm{r}^{24}$ Po kolejnym ataku na masonerię i próbie ukazania jej roli w Partii Faszystowskiej w 1927 r. Preziosi został definitywnie odsunięty poza nawias życia politycznego. W 1927 r. pozbawiono go funkcji dyrektora pisma „Mezzogiorno” (które ostatecznie w 1929 r. zostało zamknięte), a następnie także dyrekcji periodyku „Roma”. Preziosiego objęto nawet nadzorem policyjnym, a szef policji Arturo Bocchini został upoważniony do zastosowania specjalnych środków, żeby uniemożliwić mu opuszczenie kraju. Niezrażony tym Preziosi kontynuował swoją batalię ideologiczną na łamach „La Vita italiana”, która stała się dodatkiem do pisma Farinacciego „Il regime Fascista”.

W latach 30., chociaż zdawał sobie sprawę, że Mussolini nie darzył go sympatią, Preziosi starał się przekonać duce do wprowadzenia polityki antysemickiej we Włoszech. Niezależnie od tego Mussolini nie włączył go do współpracy przy opracowaniu ustaw rasistowskich w 1938 r. i wykluczył z kierownictwa instytucjami powołanymi w celu wprowadzania ich w życie. Kiedy we wrześniu 1938 r. utworzono Najwyższą Radę do spraw Demografii i Rasy (Consiglio superiore della Demografia e della razza) stanowisko to zostało powierzone prefektowi Antoniemu Le Pera, który od 1940 r. kierował także pismem „Razza e Civiltà” i który wraz z Buffarinim i Guidim zajmował się organizacją polityki rasistowskiej pod względem politycznym i ustawodawczym. Oficjalną kampanię propagandową reżimu prowadziło natomiast pismo „La Difesa della Razza”, kierowane przez Telesia Interlandiego.

Preziosi ze swej strony negatywnie odniósł się do ustaw rasistowskich z lat 1938-1939, krytykując ich zbyt łagodny charakter. Jego zdaniem niesłusznie wykluczono z nich Żydów, którzy w przeszłości oddali nadzwyczajne zasługi dla ojczyzny lub partii faszystowskiej ${ }^{25}$. Kontynuował swoją batalię na łamach „La Vita Italiana”, oskarżając amerykańskich Żydów i masonów o wywołanie II wojny światowej i sabotowanie sił zbrojnych Osi. Teoriom tym dał wyraz przy opracowaniu broszury propagandowej pt. Gli ebrei hanno voluto la guerra, która ukazała się w marcu 1942 r. Uzasadniał w niej, że data wybuchu wojny została postanowiona 3 sierpnia 1939 r. w Cap d'Antibes przez trzech wielkich przedstawicieli amerykańskiego judaizmu, a zarazem doradców prezydenta Thomasa Woodrow Wilsona: Hansa Morgenthaua, Bernarda Barucha i Wielkiego Rabina Stefana Wise’a. Wykazywał także żydowskie pochodzenie prezy-

24 Pretekstem do wykluczenia Preziosiego z listy PNF w wyborach w 1924 r. stała się kampania prasowa w sprawie malwersacji przy osuszaniu Bagien Pontyńskich, w wyniku której został podany za zniesławienie do sądu i skazany na rok więzienia w zawieszeniu. Jego przeciwnicy w PNF, wykorzystując fakt, że promowana akcja naruszyła „dobre imię Partii Faszystowskiej”, sprzeciwili się włączeniu jego nazwiska na listę partyjną.

25 Por.: przyp. 10. 
denta Franklina Delano Roosevelta oraz proklamował realizację rasizmu integralnego $\mathrm{i}$ integralna aplikacje ustawodawstwa antysemickiego. Czynił to $\mathrm{z}$ tak wielkim fanatyzmem, że w lutym 1943 r. został nawet określony przez ambasadora Niemiec Hansa Georga Victora von Mackensena sita napędowa antysemityzmu wtoskiego ${ }^{26}$.

W 1942 r. dzięki presji Farinacciego, który już od 1938 r. starał się wpłynąć na duce, żeby powierzył Preziosiemu stanowisko ambasadora lub nominację na senatora, został ostatecznie mianowany ministrem. Funkcja ta miała jednak charakter czysto honorowy, gdyż aż do 25 lipca 1943 r. Preziosi nie odgrywał żadnej konkretnej roli w życiu państwa. Utrzymywal jedynie kontakty z centrami politycznymi do studiów nad problemem żydowskim, które od 1941 r. zaczęły powstawać w całych Włoszech ${ }^{27}$. Przy współpracy z centrum w Trieście opracował czterdziestostronicowe studium pt. Propaganda nemica-Ebraismo-Fronte interno (1942), w którym starał się wykazać powiązania zagraniczne grupy judejsko-plutokratyczno-szpiegowskiej z Triestu ${ }^{28}$.

Podobnie po utworzeniu Włoskiej Republiki Społecznej nie powierzono Preziosiemu żadnego stanowiska, chociaż wysłał szereg petycji, przestróg i reprymend do Mussoliniego, starając się wykazać konieczność definitywnego rozwiązania kwestii judejsko-masońskiej we Włoszech.

Aż do 15 marca 1944 r. pozostał w Niemczech, gdzie kontynuował działalność propagandową na łamach oficjalnego organu NSDAP „Völkischer Beobachter” oraz w transmisjach nadawanych w języku włoskim za pośrednictwem Radia Monachium. Atakował w nich nieudolnych gerarchów faszystowskich, którzy dopuścili do upadku Mussoliniego, a nawet oskarżał nowych ministrów RSI Guida Buffarini Guidiego i Alessandra Pavoliniego o utrzymywanie stosunków z Żydami. Od września 1943 r. rozpoczął też wydawanie „La Vita Italiana”, które ukazywało się aż do lutego 1945 r. W dniu 31 stycznia 1944 r. napisał słynny memoriał do Mussoliniego, wyjaśniający przyczyny, które jego zdaniem doprowadziły do wydarzeń z 25 lipca ${ }^{29}$. Zaliczał do nich w pierwszym rzędzie nierozwiązanie problemów żydowskiego oraz masońskiego w życiu państwa i Partii Faszystowskiej. W liście tym przedstawiał też rozwiązanie wspomnianego problemu poprzez zupełną eliminację Żydów i usunięcie ze wszystkich urzędów osób podejrzanych o przynależność do masonerii. Spodziewał się, że wprowadzenie ustaw rasistowskich na wzór ustawodawstwa nazistowskiego doprowadzi do utworzenia nowej aryjskiej zjednoczonej Europy. Kopia listu została przesłana rów-

26 Cyt. za: M. Michaelis, Riflessioni sulla recente storia dell'Ebraismo italiano, „Rassegna Mensile d'Israel” 1977, t. 43, nr 5-6, s. 204, przyp. 39.

27 Pierwsze "Centro di preparazione politica per lo studio del problema ebraico" powstało w Anconie w 1941 r. Zostało założone przez markiza Guido Podaliri, autora książki De Republica Haebreorum (1940). Następnie utworzono analogiczne centra w Mediolanie, Florencji, Bolonii, Trieście, Genui, Bergamo, Cremonie. Zajmowały się one propagandą ideologiczną, organizując serie konferencji w celu przygotowania „świadomości rasowej” Włochów.

28 Cyt. za: T.M. Pichetto, Alle radici dell 'odio. Preziosi e Benigni antisemiti, Milano 1983, s. 95.

29 Archivio centrale dello stato (dalej: ACS), segretera particolare del Duce, RSI, CR, Giovanni Preziosi a Benito Mussolini, lettera-memoriale, 31 gennaio 1944 r., b. 24, fasc. 166. Tekst memoriału został opublikowany w: R. De Felice, Storia degli ebrei..., s. 549-601. 
nocześnie do Hitlera - wraz z dedykacją: Proszę wierzyć w moje gtębokie przywiązanie i moją niezmienna wdzięcznoścíc.

Pod wpływem nacisku ze strony Niemiec 13 marca 1944 r. Preziosi został mianowany generalnym inspektorem do spraw rasy, bezpośrednio podlegającym szefowi rządu, chociaż w rzeczywistości urząd ten był pozbawiony możliwości autonomicznego działania.

W okresie istnienia RSI, wziął także aktywny udział w dyskusji nad reorganizacją Partii Faszystowskiej, którą podjęto już w 1939 r. w momencie zastąpienia Achille Starace na stanowisku sekretarza partii faszystowskiej. Należy zaznaczyć, że Preziosi nawiązał do programu zmodyfikowania idei partii poprzez nadanie jej charakteru „elity wyznawców" i przekształcenia jej w zakon (ordine), przedstawionego już pod koniec lat 30. przez Juliusa Evolę. W koncepcji Evoli nie chodziło o utworzenie nowej wspólnoty religijnej czy zakonnej, lecz nawiązanie do historycznych organizacji rycerskich. "Zakon” oznaczać miał elitę, formację wolontariuszy o charakterze ascetycznym i wojskowym, która powinna strzec idei, a także jej zasad i tradycji. W ten sposób $w$ partii pojętej jako faszystowski zakon Imperium Wtoskiego wcielitaby się nowo idea rewolucyjna, która przywotataby najgtębsze sity rasy i przekazataby tradycję ${ }^{31}$. W latach 1943-1944 koncepcja ta znalazła pełne uznanie Preziosiego, który żywił głęboką niechęć do aktualnej formy partyjnej, wykazując, że nie potrafiła ona przeciwstawić się upadkowi faszyzmu w lipcu 1943 r. Jego zdaniem podstawą nowego porządku europejskiego miała być przynależność do rasy aryjskiej, a zakon stanowiący aryjską elitę, bazującą na elemencie rasowym, miał mieć znaczenie nadrzędne w stosunku do wyborów ideologicznych. Jak podkreślił Mauro Raspanti, analizując formularze używane przy nowych wpisach przez „Centri italiani per la razza”, wyraźnie widać, że element rasowy przy kooptacji nowych członków miał znaczenie nadrzędne. Włoski historyk podkreślił, że formularze te przypominały bardziej karty genealogiczne niż zwykły kwestionariusz: należało wypełnić deklarację rasową zainteresowanego oraz jego rodziców i dziadków, a także wpisać rasę żony i jej rodziców oraz dziadków. Dokument opatrzony był następującą formułą: Niżej podpisany deklaruje na swój honor, że nie posiada przodków rasy żydowskiej i niearyjskiej i nigdy nie należat do loży masońskiej czy jakiejkolwiek innej sekty ${ }^{32}$.

Upadek faszyzmu był dla Preziosiego ciężkim ciosem. Obawiając się nieuchronnej $i$ bezlitosnej vendetty żydowskiej, w nocy z 25 na 26 kwietnia 1945 r. wraz z żoną popelnił samobójstwo. W pożegnalnym liście napisał: Poświęcitem cate moje życie dla wielkości Ojczyzny. Poszedtem za Mussolinim, ponieważ uważatem go za cztowieka, który mógt nadać wielkość Wtochom. Po 25 lipca żywitem jeszcze nadzieje. Dziś w obliczu powszechnego upadku nie pozostaje mi nic więcej jak zakończyć życie 33 .

30 Kopia listu do Hitlera znajduje się w Archiwum Państwowym w Rzymie (ACS, RSI, SPD, CR, b. 24, fasc. 166 „Giovanni Preziosi”). Cyt. za: M. Raspanti, L'Ispettorato generale per la razza, [w:] La Repubblica sociale..., s. 111.

31 Cyt. za: J. Evola, Partito od Ordine?, „Corriere Padano” 1940, 2 I.

32 Zob.: M. Raspanti, L'Ispettorato generale..., s. 133.

33 Cyt. za: E. Canaveri, Come morirono. G. Preziosi, „Meridiano d'Italia” 1959, t. 14, nr 65, s. 14-15. 


\section{KWESTIA ŻYDOWSKA I PROBLEM MASONERII W KONCEPCJI GIOVANNIEGO PREZIOSIEGO}

Podczas gdy prawdopodobnie Preziosi stał się przeciwnikiem masonerii pod wpływem nacjonalistów ${ }^{34}$, trudno ustalić z całą pewnością, kiedy przejął idee antysemickie. Pierwszą wzmiankę o Żydach znaleźć można we wspomnianym już jego studium Gli Italiani negli Stati Uniti del Nord z 1909 r., w którym pisał: Żydzi najlepiej handluja z naszymi Wtochami, ponieważ będac prawdziwymi kosmopolitami, dostosowuja się do ich zwyczajów, mówią ich dialektem i umieją wkraść się w ich taski ${ }^{35}$. Chociaż w tych zdaniach trudno doszukać się charakteru antyżydowskiego, Preziosi, wspominając po latach 15 stycznia 1943 r. na łamach „La Vita Italiana” swój pobyt w Nowym Jorku, stwierdził, że wtedy po raz pierwszy dostrzegł przejawiajace się we wszystkich sferach życia, przede wszystkim whandlu, wykorzystywanie przez Żydów emigrantów innych narodowości, gtównie Wtochów, a także uprzywilejowana pozycje, jaka cieszyli sie w Stanach Zjednoczonych ${ }^{36}$.

W pewnym przybliżeniu można przyjąć, że Preziosi odkrył „kwestię żydowską” po zakończeniu I wojny światowej, prawdopodobnie pod wplywem Maffea Pantaleoniego. Na przełomie 1919 i 1920 r. zaczął bowiem prezentować swoje koncepcje w artykułach publikowanych w „La Vita Iitaliana” ${ }^{37}$. Ukazywał w nich powiązania pomiędzy judaizmem, masonerią a bolszewizmem. Jednocześnie winą za okaleczony pokój wersalski (pace mutilata) i upadek włoskich nadziei imperialistycznych obarczał Lloyda George'a, Thomasa Woodrow Wilsona i George’a Clemenceau, których oskarżył o bycie Żydami oraz związki z catą bandą Izraelitów. Punktem wyjścia jego teorii było twierdzenie, że $\dot{Z} y d z i$ i krypto-Żydzi sprawowali kontrolę nad światową finansjerą wraz z lożami masońskimi, a niesatysfakcjonujące zwycięstwo włoskie w I wojnie światowej było wynikiem nie błędnej polityki wewnętrznej i zagranicznej Włoch, lecz działalności wspo-

34 Na II Kongresie Nacjonalistycznym w 1912 r. w Rzymie podkreślono problem „niszczącej działalności” Wielkiego Wschodu i w konsekwencji przegłosowano projekt wykluczenia masonów z życia politycznego, gospodarczego i kulturalnego Włoch. Nieoficjalny organ Stowarzyszenia Nacjonalistów Włoskich (ANI) „L’Idea Nazionale” w 1913 r. przeprowadziła ankietę na temat niebezpieczeństwa wpływu masonerii na życie polityczne Włoch. W ankiecie wzięli udział główni przedstawiciele życia politycznego, kulturalnego i gospodarczego, a rezultaty zostały zebrane i opublikowane w osobnym tomie w $1925 \mathrm{r}$.

35 Zob.: G. Preziosi, Gli Italiani negli Stati Uniti del Nord, Milano 1909, s. 36.

36 Cyt. za: M.T. Pichetto, Le radici ideologiche e culturali dell'antisemitismo di Giovanni Preziosi, [w:] Giovanni Preziosi e la questione della razza in Italia. Atti del Convegno di studi (Avellino-Torela dei Lombardi, 30 novembre - 2 dicembre 2000), a cura di L. Parente, F. Gentile, R.M. Grillo, Soveria Mannelli 2005, s. 27.

37 Faktem jest, że jak wykazała Maria Teresa Pichetto, aż do 1919 r. „La Vita Italiana” nie tylko nie miała charakteru antysemickiego, ale wśród współpracowników tego pisma znajdowali się zarówno Żydzi, jak i masoni. Dopiero ok. 1921 r. zaczęło ono prowadzić kampanię antyżydowską i przez dłuższy czas było jedynym pismem włoskim o charakterze antysemickim. Z „La Vita Italiana” współpracowali czołowi antysemici włoscy, jak Julius Evola, Sommi Picenardi, Gherardo Maffei. Zob.: M.T. Pichetto, Alle radici dell'odio. Preziosi e Benigni antisemiti, Milano 1983, s. 42; M. Sarfatti, Presentazione, [w:] La Repubblica Sociale Italiana..., s. 10. 
mnianego spisku tajnych sił międzynarodowych. W artykule pt. Ebraismo, massoneria e bolscevismo in Francia stwierdził: Wszyscy wiedza, jakie związki zachodza między masoneria a judaizmem. Sq one tą samq rzeczą; doktadniej mówiąc judaizm postuguje się organizacja masońska, wykorzystujac jej powiazania. $Z$ drugiej strony rewolucja bolszewicka, jak każdy wie, byta $z$ ducha $i$ źródet judejską.

W świetle tej koncepcji bolszewizm był więc pochodną judaizmu, masoneria natomiast jego głównym narzędziem. Źródeł zależności masonerii od judaizmu we Włoszech Preziosi upatrywał w okresie risorgimenta. We wstępie do Protokotów mędrców Syjonu napisat: większa część klasy sprawujacej rzady we wszystkich sektorach, w szczególności w sitach zbrojnych, sztukach pięknych, robotach publicznych należata do masonerii i niemato byto także Żydów. Nie należacy do masonerii znaczyli bardzo mato i nie mieli możliwości zrobienia kariery $w$ administracji publicznej ${ }^{39}$.

Maria Teresa Pichetto łączy moment przyjęcia przez Preziosiego idei antysemickich w 1920 r. z jego odejściem od ruchu nacjonalistycznego, któremu zarzucał negowanie problemu żydowskiego czy wręcz podkreślanie znaczenia Żydów we Wtoszech ${ }^{40}$. Włoska historyk stara się także wytłumaczyć owo „nawrócenie na antysemityzm” lekturą tekstów, które ukazały się na przełomie 1919 i 1920 r., w szczególności antyżydowskich pamfletów niemieckich, francuskich, angielskich i amerykańskich oraz antysemickich broszur i gazet. Brak natomiast wśród pozycji wykorzystanych przez Preziosiego prac włoskich, których jak podkreśliła Pichetto, na początku lat 20. praktycznie jeszcze nie było. Cytowana autorka wykazała, że wśród tekstów najczęściej wymienianych przez rasistowskiego ideologa znalazł się - założony w 1892 r. przez twórcę mitu konspiracji judejsko-masońskiej jako czynnika wpływającego na francuskie życie polityczne Édoaurda Drumonta - dziennik „La Libre Parole”, a oprócz niego „La Vieille France” - pismo Urbaina Gohiera, który w 1920 r. opublikował także La conspiration juive. "Protocols" procés verbaux des reunions secrètes des sages d'Israel, oraz „Morning Post”. W tym ostatnim latem 1920 r. ukazała się seria 18 artykułów poświęconych zagrożeniu żydowsko-masońskiemu, zebranych następnie w tomie pt. The Cause of World Unrest (1920). Ponadto Preziosi korzystał z publikacji „Dearborn Independent”, pisma Henry'ego Forda, który od maja do października 1920 r. ogłosił szereg artykułów, opublikowanych następnie w The International Jew. The World's Foremost Problem. Należy zaznaczyć, że to ostatnie studium zostało przetłumaczone na język włoski i pod tytułem L'ebreo internazionale. Un problema del mondo ukazało się w 1938 r., natomiast Preziosi poświęcił Fordowi dwa artykuły w „La Vita Italiana”: Dagli a Ford! i Il caso Ford. Jeszcze w 1942 r. wspominał, że pismo [Forda - przyp. J. S.-C.] przeprowadzito jedna z najlepszych i najlepiej udokumentowanych kampanii przeciwko próbom podporzadkowaniu Stanów Zjednoczonych Żydom ${ }^{41}$.

\footnotetext{
Cyt. za: M.T. Pichetto, Alle radici dell'odio..., s. 37.

Zob.: I Protocolli dei..., s. 26.

Zob.: G. Preziosi, Giudaismo, bolscevismo, plutocrazia..., s. 55.

41 Zob.: tenże, Dagli a Ford!, „La Vita Italiana” 1933, nr 42, s. 468; tenże, Il caso Ford, „La Vita Italiana” 1942, nr 59, s. 285-287. Cyt. za: M.T. Pichetto, Le radici ideologiche..., s. 36.
} 
Spośród wszystkich wspomnianych tekstów największe znaczenie w formacji ideologicznej Preziosiego odegrały Protokoty mędrców Syjonu, które przetłumaczył na język włoski i wraz ze wstępem krytycznym opublikował w 1921 r. Należy zaznaczyć, że począwszy od 1921 r., Protokoty nie cieszyły się we Włoszech szczególnym zainteresowaniem, a jedynym czasopismem, które poświęciło im więcej uwagi, była „La Vita Italiana”. Od 1921 do 1938 r. Preziosi zamieścił na jego łamach szereg artykułów na temat domniemanego autora Protokotów - Siergieja Nilusa, a także kwestii ich autentyczności, rozpowszechniania i źródeł. Odpowiadając w szczególności na zarzuty o wątpliwy autentyzm tekstu we wstępie napisanym w 1921 r. stwierdził, że miało to znaczenie drugorzędne, ponieważ jego zdaniem o wiele ważniejsza była prawdziwość zawartych w Protokotach informacji. Podkreślał jednocześnie, że jego poglądy nie były przejawem antysemityzmu, lecz opierały się na faktach. W żadnym innym kraju Żydom nie żyło się bowiem tak dobrze jak we Włoszech. Niemniej jednak przyczyn kryzysu gospodarczego, który dotknął Włochy po I wojnie światowej, a także upadku perspektyw ekspansjonistycznych dopatrywał się we wpływie międzynarodowego spisku demokracji zachodnich, masonerii, socjalizmu, bolszewizmu, opanowanych przez Żydów. Ta tajna potęga żydowska miała zmierzać do podporządkowania sobie słabszych krajów, w pierwszym rzędzie Włoch. Koncepcji tej Preziosi dał wyraz w artykule pt. E in Italia, który ukazał się w „La Vita Italiana” w lutym 1921 r. Pisał w nim m.in.: $\dot{Z} y d z i$, chociaż sa mniejszościa, odgrywają we Wtoszech dominująca rolę: zajmują ważne stanowiska w centrach newralgicznych państwa [...] stoja na czele wielkich banków, sq licznie reprezentowani w Senacie i w Izbie Deputowanych; zajmuja czotowe pozycje wadministracji państwowej. W dziedzinie szkolnictwa sa bardzo liczni [...] Mają w swoich rękach prawie wszystkie wydawnictwa. I dodajmy, że najwięksi i najbardziej wptywowi demagodzy, jak i najaktywniejsi agitatorzy sa Żydami ${ }^{42}$.

Należy zaznaczyć, że początkowo Preziosi nie był negatywnie nastawiony do syjonizmu, aczkolwiek dopatrywał się niebezpieczeństwa związanego z „podwójną narodowością" Żydów włoskich sympatyzujących z tym ruchem. W artykule Il Sionismo e l'internazionale ebraica krytykował "Żydów kosmopolitów”, którzy będąc syjonistami chca, żeby Izraelici rozprzestrzenieni po catym świecie, cieszyli się prawami obywateli poszczególnych państw i wymagaja jednocześnie, żeby te państwa uznaty przywileje państwa Izrael $^{43}$.

Jak podkreśliła Maria Pichetto, w latach 30. Preziosi był jeszcze „umiarkowanym antysemitą”. W swoich artykułach krytykował przede wszystkim internacjonalizm Żydów, a także ich rzekome tendencje do wykorzystywania innych narodów pod względem gospodarczym: Wtochy chca, żeby sytuacja Wtochów o pochodzeniu żydowskim byta taka sama jak wszystkich innych obywateli wtoskich - deklarowat w artykule Niente antisemitismo w maju 1934 r. I dodawał: Jesteśmy przeciwko Izraelowi-sekcie, tej, która od tysięcy lat wykorzystuje świat, a nie przeciwko Żydom jako takim ${ }^{44}$.

\footnotetext{
42 Cyt. za: G. Preziosi, E in Italia?, „La Vita Italiana” 1921, nr 17.

43 Zob.: tenże, Il Sionismo e l'internazionale ebraica, „La Vita Italiana” 1921, nr 17, s. 21.

44 Cyt. za: M.T. Pichetto, Le radici ideologiche..., s. 40.
} 
Sankcje gospodarcze po wojnie z Etiopią oraz polityczne zbliżenie Włoch z Niemcami w 1936 r., które doprowadziły do wzrostu nastrojów antysemickich we Włoszech, przyniosły także radykalizację poglądów Preziosiego w kwestii żydowskiej. Po ukazaniu się książki Paola Orana pt. Gli ebrei in Italia w 1937 r., w której autor krytykował zarówno ruch syjonistyczny, jak i Żydów-faszystów, Preziosi negatywnie ocenił to opracowanie, twierdząc, że autor potraktował w nim problem zbyt łagodnie. Uzasadniał istnienie tzw. „istoty żydostwa” (essenza ebraica), niezmiennej i trwałej, która sprawiała, że Żyd pozostawał na zawsze Żydem, niezależnie od narodowości, wyznawanego credo politycznego czy nawrócenia na katolicyzm. Zdaniem Preziosiego rasa w przypadku Żydów nie była jedynie faktem biologicznym, antropologicznym, lecz prawem zawartym w Biblii i Talmudzie. Istnieniem owej „istoty żydostwa” uzasadniał działalność międzynarodówki żydowskiej, będącej światową organizacją, za pośrednictwem której Żydzi prowadzili akcję wywrotową we wszystkich sferach życia, od nauki po finanse, od literatury po psychologię.

W okresie istnienia Włoskiej Republiki Społecznej Preziosi kontynuował swoją antysemicką i antymasońską batalię ideologiczną na łamach czasopism. Opublikował także dziesięciopunktowy program działalności kierowanego przez siebie Głównego Inspektoratu do spraw Rasowych, podkreślając w szczególności konieczność walki z polityką arynizacji, którą uważał za anomalię prawną do wyeliminowania, oraz potępiając solidarność masonów i Żydów. Oficjalnym organem Inspektoratu stało się pismo„La Vita Italiana”, które wznowiło swoją działalność we wrześniu 1944 r. Na jego łamach publikowali teksty politycy blisko związani z Inspektoratem, jak Piero Pisenti i Rodolfo Graziani, a także najbardziej znani teoretycy rasizmu faszystowskiego: Giulio Cogni, Telesio Interlandi, Massimo Scaligero i Lidio Cipriani ${ }^{45}$. W dniu 18 marca 1944 r. ukazał się także pierwszy numer tygodnika włoskich ochotników SS „Avanguardia Europea”, w którym Preziosi opublikował długi artykuł pt. Perchè?, przedstawiając historię swojej przeszło dwudziestoletniej walki z tajemnymi sitami żydowsko-masońskimi. Należy zaznaczyć, że pierwsze dwa numery pisma były redagowane przez wiernego ucznia i przyjaciela Preziosiego, Felice Bellottiego, dziennikarza, wyższego oficera we włoskim SS, odpowiedzialnego za propagandę w tej formacji. W kwietniu 1944 r. pod pseudonimem Italicus Preziosi opublikował natomiast studium pt. Il tradimento di Badoglio, w którym przedstawił przyczyny, jakie jego zdaniem doprowadziły do upadku faszyzmu 25 lipca 1943 r. Stwierdził w tym studium, że do wydarzeń lipcowych mogło dojść, ponieważ żaden inny kraj na świecie nie uległ tak silnym wpływom żydowskim i masońskim jak Włochy. W szczególności przedstawiając karierę wojskową marszałka Pietra Badoglia od czasów I wojny światowej, uznał go za narzędzie w ręku „żydo-masonerii”. Oprócz Badoglia atakował także większość gerarchów faszystowskich, a w szczególności Giuseppe Volpiego, Luigiego Federzoniego, Giuseppe Bottaia i Giacoma Acerbę, którego koncepcję doktryny rasistowskiej skrytykował już wielokrotnie na łamach „La Vita Italiana".

45 Początkowo organem oficjalnym Ispettorato miało być „Razza e Civiltà”, które od 1940 r. było pismem Najwyższej Rady do spraw Demografii i Rasy oraz Dyrekcji Generalnej do spraw Demografii i Rasy. 
Preciozi przystąpił także do ponownej publikacji swoich głównych dzieł. W maju 1944 r. nakładem wydawnictwa Mondadori w Mediolanie ukazało się trzecie wydanie jego głównego dzieła, a mianowicie Giudaismo, bolscevismo, plutocrazia, massoneria, w którym proklamował konieczność integralnego rozwiązania problemu żydowskiego ${ }^{46}$, a w listopadzie 1944 r. i w styczniu 1945 r. - siódma i ósma edycja Protokotów mędrców Syjonu ${ }^{47}$. W styczniu 1945 r. wyszło także drukiem studium Francesca Gaeta pt. La massoneria ze wstępem i w opracowaniu Preziosiego.

Jak podkreślił historyk Mauro Raspanti, cała działalność publicystyczna Preziosiego w okresie RSI znajdowała się pod wpływem rasizmu ezoteryczno-tradycyjnego, którego podstawy opracowal Julius Evola, a także koncepcji biologicznych narodowego socjalizmu. Wspomniany autor określił koncepcje rasistowskie Preziosiego jako „rasizm bio-duchowy" (bio-spirituale), w myśl którego kropla krwi żydowskiej wystarczyta do uznania kogoś za Żyda ${ }^{48}$. Należy podkreślić, że zarówno Preziosi, jak i Evola krytykowali koncepcje rasizmu nacjonalistycznego (nazional-razzismo), trendu szczególnie popularnego pomiędzy 1939 a 1941 r., którego głównymi ideologami byli Giacomo Acerbo, autor dzieła I fondamenti della dottrina fascista della razza (1940), oraz autor Razza e Nazione (1942) - Vincenzo Mazzei.

Preziosi, krytykując założenia faszystowskiej polityki rasistowskiej, szczególnie negatywnie odniósł się do przepisu zatwierdzonego na posiedzeniu Wielkiej Rady Faszystowskiej w dniu 7 października 1938 r., który uznawał za osoby rasy żydowskiej tylko urodzonych z obojga rodziców żydowskich, co wykluczało z tego kręgu dzieci pochodzące z mieszanych małżeństw jako ludzi rasy aryjskiej i narodowości wtoskiej. Preziosi dał temu wyraz w artykule pt. La battaglia antiebraica è fallita?, który ukazał się w 347 numerze „La Vita Italiana” w lutym 1942 r., gdzie stwierdził m.in.: Wspomniana norme pogarsza jeszcze fakt, że Żydów ochrzczonych nie uważa się za rasy żydowskiej. Tak jakby woda chrzcielna mogta zmienić rodzaj krwi. W ten sposób na skutek świadectw chrztu powiększyliśmy liczbę Aryjczyków i zmniejszyliśmy liczbę Żydów ${ }^{49}$. Preziosi podkreślał, że tak sformułowana ustawa utrudniała jedynie odróżnienie Żydów od nie-Żydów o krwi żydowskiej. Uważał, że przynosiła ona korzyść Żydom, a nawet dopatrywał się w tym unormowaniu spisku żydowskiego ${ }^{50}$. W celu rozwiązania tego problemu proponował wprowadzenie zmodyfikowanej Karty Rasowej (Carta della Razza), będącej certyfikatem aryjskości dla każdego obywatela włoskiego. Propozycję tę przedstawił Farinacciemu jesienią 1940 r. Tekst projektu został opublikowany 17 października 1940 r. w „Il Regime Fascista”, a w listopadzie tego samego roku w „La Vita Italiana”.

46 Pierwsze wydanie dzieła Giudaismo, bolscevismo, plutocrazia, massoneria ukazało się w 1941 r., drugie natomiast w $1943 \mathrm{r}$.

$47 \quad$ Zob.: I Protocolli dei... Jednocześnie też z inicjatywy Ministerstwa Kultury Ludowej ukazała się inna wersja, bez komentarza i przypisów Preziosiego. Zob.: I Protocolli dei Savi Anziani di Sion dettati al mondo dall 'Internazionale ebraica, Torino 1944.

48 Zob.: M. Raspanti, L'Ispettorato generale..., s. 137.

4 Zob.: La battaglia antiebraica è fallita?, „La Vita Italiana” 1942, nr 30, s. 176.

50 Zob.: A proposito degli ebrei che si autoqualificano,figli di prostituta, „La Vita Italiana” 1941, nr 29, s. 304 . 
Znalazł on pełne poparcie Juliusa Evoli, jak można wnioskować z treści artykułu pt. La situazione del razzismo in Italia, który ukazał się w lutym $1941 \mathrm{r}$. Evola proklamował w nim potrzebę sprawdzania przynależności rasowej aż do trzech pokoleń wstecz, jak to czyniono w Niemczech ${ }^{51}$. Polemizował też z normą szczególnych zastug oddanych dla ojczyzny lub faszyzmu, która jego zdaniem nie może nadawać aryjskiego charakteru osobie rasy żydowskiej ${ }^{52}$. Jak podkreślił Francesco Cassata, projekt zaostrzenia ustawodawstwa rasistowskiego przedstawiony przez Evolę i Preziosiego był częścią szerszej polityki wyniszczenia Żydów włoskich. Opierała się ona na idei „Żyd = wróg absolutny”, który nie może zostać zasymilowany i z którym nie można mieć innych kontaktów poza użyciem siły.

\section{PREZIOSI A NIEMCY}

Jak podkreśliła Maria Teresa Pichetto, na przełomie czerwca i sierpnia 1922 r. uległ zmianie stosunek Preziosiego do Niemiec, czemu publicysta dał wyraz w artykułach: Walter Rathenau fu assassinato perché ebreo, poświęconym zabójstwu niemieckiego ministra spraw zagranicznych przez kilku fanatyków uważających Rathenaua za jednego z „mędrców Syjonu”, oraz Gli ebrei, la passione e la resurrezione della Germania, który został napisany po spotkaniu Preziosiego z grupą antysemitów niemieckich w Rzymie 26 lipca 1922 r. Wspomniane teksty świadczą, że zapoznał się on z antysemickimi artykułami Alfreda Rosenberga, które ukazały się w latach 1919-1923. Bardzo pozytywnie odniósł się do wzrostu znaczenia NSDAP w życiu politycznym Niemiec pod koniec lat 20. i do przejęcia przez Hitlera władzy w 1933 r. W szczególności w artykule pt. Hitler dał wyraz swojej sympatii dla nazizmu i głoszonych przez niego idei antysemickich ${ }^{53}$. Jak podkreśliła Teresa Maria Pichetto, Preziosi nie podzielał jednak neopogańskich koncepcji Rosenberga, a w szczególności uważał za szkodliwe tworzenie nowej neogermańskiej religii germańskiej. Nie zgadzał się też z tendencjami do zwalczania Kościoła rzymskokatolickiego ${ }^{54}$.

W latach 30. Preziosi utrzymywał kontakty z nazistowskimi instytucjami zajmującymi się polityką antysemicką, podobnie zresztą jak czynili to inni teoretycy włoskiego rasizmu - Giulio Cogni i Julius Evola. W dniu 11 czerwca 1941 r. napisał list do dra Wilhelma Graua, szefa Instytutu Badań nad Kwestią Żydowską we Frankfurcie, prosząc o informacje dotyczące działalności Instytutu, wyrażając jednocześnie nadzieję na stworzenie podobnej placówki we Włoszech. Owe kontakty z hitlerowskimi Niemcami musiały być tak zażyłe, że 29 czerwca 1942 r. E. Düssel, dyrektor Fundacji

Zob.: J. Evola, La situazione del razzismo in Italia, „La Vita Italiana” 1941, nr 29.

52 Zob.: tenże, La razza dell'anima, l’onore e le arianizzazioni, „Il Regime Fascista” 1941, nr 26.

53 Świadczy o tym seria artykułów, m.in.: G. Preziosi, La nuova tappa di Hitler, „La Vita Italiana” 1932, nr 40, s. 233; tenże, Saluto a Hitler, „La Vita Italiana” 1933, nr 41, s. 225; tenże, Attenti!, „La Vita Italiana" 1942, XI, s. 600.

54 Dał temu wyraz w artykule Se fossi un tedesco, który ukazał się we wrześniu 1934 r. 
Studiów Włosko-Niemieckich, zwrócił się z prośbą o informację o Preziosim do przebywającego w Rzymie SS-Obersturmbannführera Eugena Dollmanna w związku z zamiarem przyznania Preziosiemu doktoratu honoris causa przez jeden z niemieckich uniwersytetów. Dollmann skierował to pytanie do sekretarza kulturalnego przy ambasadzie Niemiec, dra Albrechta von Kessel, który jednak stwierdził, iż nie negując zastug Preziosiego $w$ walce zjudaizmem, przyznanie tak wysokiego odznaczenia byto nieuzasadnione. Albrecht sugerował inny rodzaj uznania: jakiś medal czy zaproszenie na podróż do Niemiec 55 .

Hitlerowskie Niemcy jednak, w przeciwieństwie do Mussoliniego, żywiły dla Preziosiego duży szacunek, doceniając jego wierność wobec Führera i determinację w prowadzeniu kampanii antysemickiej we Włoszech. Nieprzypadkowo też w nocy z 25 na 26 lipca 1943 r. Preziosi został, na polecenie Hitlera, przetransportowany przez SS samolotem do twierdzy w Rastenburgu i on to przypuszczalnie jako pierwszy przedstawił niemieckiemu przywódcy szczegóły antymussolińskiego zamachu. Z Niemiec powrócił dopiero po powierzeniu mu nowej funkcji inspektora do spraw rasowych w 1944 r., chociaż Alfred Rosenberg proponował go nawet na stanowisko szefa rządu Włoskiej Republiki Społecznej.

\section{DZIAŁALNOŚĆ I ZNACZENIE GENERALNEGO INSPEKTORATU DO SPRAW RASOWYCH (ISPETTORATO GENERALE PER LA RAZZA)}

Generalny Inspektorat do spraw Rasowych powstał na mocy dekretu nr 171 z 18 kwietnia 1944 r., z połączenia kompetencji w kwestii rasowej Ministerstwa Kultury Ludowej („Minculpop”) i Ministerstwa Spraw Wewnętrznych. Celem Inspektoratu było przeprowadzenie pełnej arynizacji kultury i społeczeństwa włoskiego, dejudaizacji i demasonizacji, co miało być koniecznym krokiem do stworzenia nowej, zjednoczonej, aryjskiej Europy i nowego porządku europejskiego. Współcześni historycy są zgodni, że bezpośrednią przyczyną utworzenia Inspektoratu i powierzenia jego kierownictwa Preziosiemu było opracowanie przez niego Memoriału i naciski na Mussoliniego ze strony Niemiec (w pierwszym rzędzie ze strony Josepha Goebbelsa i Alfreda Rosenberga $)^{56}$.

Jak podkreślił jednak historyk Francesco Cassata, utworzenie Inspektoratu nie było „desperackim gestem” Mussoliniego, który obawiał się przejęcia przez Niemcy kontroli nad polityką rasistowską we Włoszech, lecz raczej realizacją projektu polityczne-

Zob.: L. Picciotto, La macchina antiebraica..., s. 35.

56 W dniu 8 marca Preziosi przesłał telegram sekretarzowi stanu Auswärtiges Amt Adolfowi von Steengracht, w którym informował o utworzeniu Inspektoratu i podkreślał, iż zamierza pracować w ścisłym kontakcie z kompetentnymi w tej materii biurami niemieckimi w imię wspólnej aryjskiej Europy, o która wielka germańska Rzesza pod wodzq Führera prowadzi wojnę. Telegram znajduje się w Archiwum Ministerstwa Spraw Zagranicznych (Archivio Storico Diplomatico del Ministero degli Affari Esteri, RSI, Gab., b. 21, fasc. „Preziosi”). Cyt. za: G.S. Rossi, Mussolini e il diplomatico, Soveria Mannelli 2005, s. 163. 
go, przedstawionego już w 1941 r. przez frakcję ezoteryczno-tradycyjną faszystowskiego rasizmu i reprezentowaną na poziomie ideologicznym przez Preziosiego i Juliusa Evolę ${ }^{57}$. Punktem wyjścia wspomnianego projektu miała być rewizja polityki rasistowskiej zainaugurowanej przez Manifesto della razza w lipcu 1938 r., która jak zaznaczył Preziosi, nie wyznaczyta totalitarnych koncepcji faszystowskiej teorii rasy, i rozpoczęcie „drugiej fazy” tej polityki, opierającej się na zaostrzeniu ustawodawstwa rasistowskiego poprzez stworzenie organu do spraw rasowych, lączącego różne instytucje rozproszone po kilku ministerstwach.

Pierwszy udokumentowany ślad zamiaru utworzenia Inspektoratu można odnaleźć w protokołach Rady Ministrów RSI z 12 lutego 1944 r., w których występuje wzmianka o dekrecie stworzenia Ispettorato Generale della Razza w oparciu o propozycję duce, szefa rządu. Wspomniane biuro miało wchłonąć Dyrekcję do spraw Demografii i Rasy Ministerstwa Spraw Wewnętrznych (Direzione della Demografia e Razza) oraz Centrum Studiów nad Problemem Żydowskim Ministerstwa Kultury Ludowej (Centro di Studio sul problema ebraico) i podlegać bezpośrednio szefowi rządu. Oficjalnie Giovanni Preziosi otrzymał stanowisko głównego inspektora do spraw rasowych w dniu 13 marca 1944 r. i trzy dni później wiadomość o tej nominacji została podana przez agencję Stefani oraz opublikowana w prasie codziennej. Oficjalna notka głosiła: $w$ ramach dziatalności gabinetu premiera zostat utworzony Naczelny Inspektorat do Spraw Rasy i Demografii, który powierzono ministrowi Giovanniemu Preziosiemu, dyrektorowi czasopisma „La Vita Italiana ${ }^{\text {"58 }}$. Na siedzibę Inspektoratu wyznaczono Desenzato del Garda, małą miejscowość w północnych Włoszech, w pobliżu Bergamo. W wyniku szeregu spotkań z Mussolinim i ministrem Guidem Buffarini Guidim, które odbyły się w marcu 1944 r., postanowiono podzielić Generalną Dyrekcję do spraw Demografii i Rasy (tzw. „Demorazza”), przydzielając Inspektoratowi kwestię rasową i pozostawiając część demograficzną w gestii Ministerstwa Spraw Wewnętrznych. Minister Buffarini Guidi nie był skłonny przekazać Preziosiemu w szczególności zagadnień związanych z problematyką macierzyństwa i wychowania dzieci. Następnie doszło także do konfliktu pomiędzy nowym Inspektorem a ministrem finansów Giampietrem Pellegrinim, który nie zamierzał zrezygnować z uprawnień do rozporządzania sekwestrowanym majątkiem żydowskim, dotąd podlegającym Przedsiębiorstwu Zarządzania i Likwidacji Nieruchomości (Ente di gestione e liquidazione immobiliare - „Egeli”).

Ostatecznie Inspektorat powstał na mocy dekretów z 18 i 28 kwietnia 1944 r. i na przełomie wiosny i lata 1944 r. skompletowano skład personalny nowej instytucji: generalnym dyrektorem został mianowany Francesco Saverio Siniscalchi - członek dyrekcji Partii Faszystowskiej (PNF) i sekretarz federalny w Neapolu, szefem gabinetu został sędzia Carlo Alliney, sekretarzem Giovanni Pestalozza - założyciel i sekretarz PNF w Savonie i członek Centro per lo studio del problema ebraico w Mediolanie. Ettore

57 W szczególności pierwszoplanową figurą rasizmu ezoteryczno-tradycyjnego stał się od 1937 r. Julius Evola. Zob.: F. Cassata, „Guerra all 'ebreo”. La strategia razzista di Giovanni Preziosi e Julius Evola (1937-1943), [w:] La Repubblica Sociale Italiana..., s. 45. 
Martinoli, dyrektor Centrum Studiów nad Problemem Żydowskim w Trieście, został natomiast mianowany szefem oddziału studiów i propagandy. Wśród współpracowników Inspektoratu (w sumie 26) znalazł się także jeden z najbardziej aktywnych teoretyków rasizmu i antysemityzmu faszystowskiego, Lidio Cipriani - antropolog, firmatariusz słynnego Manifesto degli scienziati razzisti z 14 lipca $1938 \mathrm{r}$.

Celem Inspektoratu miało być: 1) sprawdzanie przynależności rasowej, 2) kontrola nad stosowaniem ustawodawstwa rasistowskiego, 3) opracowanie statystyk, 4) zbieranie informacji o masonerii, plutokracji i innych tajnych siłach (forze occulte). Inspektorat zajmował się także promocją studiów nad rasizmem i antysemityzmem w porozumieniu z instytutami niemieckimi, które badały te same kwestie ${ }^{59}$.

Zaraz po objęciu nowego stanowiska w kwietniu 1944 r. Preziosi przy współpracy z Carlem Allineyem przystąpił do przygotowania projektu nowych, dużo bardziej restrykcyjnych ustaw rasistowskich, a także projektu zakładającego ograniczenie praw cywilnych masonów i byłych masonów. Prowizoryczny szkic pierwszych trzech ustaw $^{60}$ po przedyskutowaniu treści z Mussolinim i ministrem sprawiedliwości Pierem Pisentim został 15 maja przesłany do akceptacji ministra Guida Buffarini Guidiego, który dokonał ostatecznej korekty tekstu. Jak wykazał Sławomir Pyciński, pierwotny projekt ustawy miał wyglądać następująco: 1) za obywateli włoskich uznawano osoby krwi włoskiej, których przodkowie w prostej linii zamieszkiwali Włochy od 1800 r., aż do drugiego stopnia mogli wykazać się pochodzeniem aryjskim oraz byli wolni od „krzyżówek” z Żydami i innymi rasami „obcymi” (z grup pozaeuropejskich); 2) za osoby obcej krwi uznano Żydów oraz tych wszystkich, którzy nie należeli do rasy aryjskiej; 3) zdefiniowano także status mieszańców pierwszego stopnia (wszystkie osoby, których jeden z rodziców był obcej krwi), zrównanych w prawach z osobami krwi obcej, oraz mieszańców drugiego stopnia (przynajmniej jeden z przodków drugiego stopnia był obcej krwi), zrównanych w prawach z osobami krwi włoskiej ${ }^{61}$.

Dodatkowym zaostrzeniem przepisów miało być wprowadzenie zasady, że osoby krwi włoskiej wchodzące w związek małżeński z mieszańcem pierwszego stopnia też były uznawane za mieszańców pierwszego stopnia, przy czym Preziosi dążył do tego, żeby również trafiały one do obozów. Zakazano jednocześnie związków pozamałżeńskich Włochów z osobami krwi obcej i mieszańcami pierwszego stopnia, a także wprowadzono pojęcie „hańby rasowej”. O pochodzeniu rasowym miała zaświadczać specjalna „tablica przodków”, stanowiąca załącznik do dokumentów osobowych. Miała także nastąpić weryfikacja wcześniej wydanych zaświadczeń. Należy zaznaczyć, że w celu identyfikacji osób podlegających ustawom rasistowskim Preziosi zamierzał posłużyć się spisami z 22 sierpnia 1938 r., a także dokumentami z archiwów „Demorazza”, Ufficio studi e propaganda sulla razza i instytucji żydowskich, do których otrzymał dostęp za zgodą Buffariniego Guidiego 11 października 1944 r.

\footnotetext{
59 Zob.: L. Picciotto, La macchina antiebraica..., s. 40.

60 Ustawy nosiły nazwy: 1) o definicji i rozróżnieniu rasowym, 2) o stanowisku prawnym Włochów o krwi obcej lub mieszanej i 3) o składzie komisji do spraw rasowych.

${ }^{61}$ Zob.: S. Pyciński, Matżensstwa „mieszane” w faszystowskich Wtoszech..., s. 259-260.
} 
Jak wykazał Mauro Raspanti, minister Buffarini Guidi dokonał poważnego okrojenia przesłanego mu projektu ustawy, a w szczególności znacznie zmodyfikował część dotyczącą kwestii rodziny i małżeństwa (artykuły 7, 8 i 9), które miały pozostać w kompetencji Dyrekcji do spraw Demograficznych Ministerstwa Spraw Wewnętrznych. Porównując obie wersje tekstu, można stwierdzić, że największe zmiany wprowadzono w artykule 7, dotyczącym dzieci nieznanych rodziców. Podczas gdy pierwotna wersja brzmiała: dzieci nieznanego ojca uważa się za przynależne do kategorii rasowej matki, wytaczywszy sytuacje, gdy przeprowadzono dowód przeciwny, po korekcjach Buffariniego Guidiego słowo ojciec zastąpiono terminem rodzic, a słowo matka zmieniono na znany rodzic ${ }^{62}$. Minister spraw wewnętrznych krytycznie odniósł się także do pierwszego artykułu, dotyczącego kwestii krwi wtoskiej, głoszącego, że krwi wtoskiej sa wszyscy obywatele wtoscy, których przodkowie mieszkaja we Wtoszech przynajmniej od 1 stycznia 1800 roku i sa rasy aryjskiej, nieskażonej powiazaniami z Żydami i innymi rasami. Zdaniem ministra wstawka o innych rasach czyniła tekst artykułu mało przejrzystym, albowiem podczas gdy można było naukowo wyznaczyć kryteria przynależności do rasy żydowskiej, trudno było równie jasno określić różnice pomiędzy rasą aryjską a wspomnianymi rasami mieszanymi.

Jak wynika z korespondencji szefa Oddziału Bezpieczeństwa Reich (RSHA) Ernesta Kaltenbrunnera i osobistego sekretarza Hitlera Martina Bormanna z 16 sierpnia 1944 r., minister spraw wewnętrznych zablokował także projekt ustawy uderzającej w masonerię ${ }^{63}$. Jak stwierdził Mauro Raspanti, stanowisko Buffariniego Guidiego w tej kwestii było spowodowane względami osobistymi, a nie ideowymi. W młodości był on członkiem loży masońskiej i chociaż stanowiło to zamknięty rozdział w jego życiu, to jednak zdawał sobie sprawę, że dla Preziosiego pozostawato się masonem na $z a w s z e^{64}$.

Oprócz rozwiązania kwestii żydowskiej pod względem normatywnym nowo mianowanemu inspektorowi szczególnie leżała na sercu sprawa przejęcia kontroli nad Przedsiębiorstwem Zarządzania i Likwidacji Nieruchomości („Egeli”). W myśl dekretu z 31 marca 1944 r. o nowym statucie i regulaminie Przedsiębiorstwa Zarządzania i Likwidacji Nieruchomości członek rady Egeli miał być przedstawicielem Inspektoratu. Od maja 1944 r. Egeli co miesiąc wysyłała do wglądu inspektora kopię statystyki skonfiskowanego mienia żydowskiego. Preziosi dążył jednak do przejęcia pełnej kontroli nad tą instytucją, co ostatecznie doprowadziło do konfliktu z ministrem finansów Giampietrem Pellegrinim, który 8 lipca wysłał list z protestem do Mussoliniego, uzasadniając to faktem, że takie posunięcie przyniosłoby jedynie niepotrzebne „komplikacje biurokratyczne”. Niezależnie od tego 7 października 1944 r. Preziosi zażądał materiałów archiwalnych dotyczących gmin żydowskich i synagog skonfiskowanych przez perfektów i przekazanych Ministerstwu Spraw

62 Pełny tekst definitywnej wersji ustawy został opublikowany przez Renza De Felice w Ebrei sotto il fascismo. Zob. także: G. Mayda, Ebrei sotto Salò, Milano 1978, s. 247.

63 Zob.: M. Raspanti, L'Ispettorato generale..., s. 120.

64 Tamże. 
Wewnętrznych, a dodatkowo w grudniu 1944 r. Buffarini Guidi przekazał mu dokumentację z Direzione generale per la demografia e la razza.

$\mathrm{Na}$ skutek oporu ministra spraw wewnętrznych Guida Buffarini Guidiego oraz niechęci samego duce projekt ustaw rasowych opracowany przez Preziosiego w maju 1944 r. na wzór rozwiązań nazistowskich nie został wprowadzony w życie. Podobnie też fiaskiem zakończyły się próby zwiększenia kompetencji Inspektoratu oraz stworzenia nowego organizmu politycznego w formie „superpolicji do spraw rasowych”, która miała zajmować się wyszukiwaniem Żydów i sekwestrem ich mienia. Dopiero w ostatnich dniach istnienia Włoskiej Republiki Społecznej, już w obliczu zbliżających się sił alianckich, na ostatnim posiedzeniu Wielkiej Rady Faszystowskiej w dniu 16 kwietnia 1945 r. został ostatecznie przegłosowany projekt dekretu przewidującego rozwiązanie związku gmin żydowskich i instytucji zajmujących się pomocą dla Żydów oraz konfiskatę ich mienia. Przyjęty in articulo mortis włoskiego faszyzmu dekret ten nie został już zrealizowany w praktyce.

Rzeczywisty wkład Giovanniego Preziosiego w dziedzinie polityki rasistowskiej włoskiego faszyzmu w latach 1943-1945 stanowi przedmiot sporu współczesnych historyków i politologów. Wybitny znawca włoskiego faszyzmu prof. Renzo De Felice w monumentalnym dziele Storia degli ebrei italiani sotto il fascismo stwierdzit, że charakter polityki antysemickiej RSI wyznaczyli Niemcy, albo bezpośrednio, albo za pośrednictwem zaufanego cztowieka - Giovanniego Preziosiego ${ }^{65}$. Część historyków minimalizuje jednak znaczenie działalności rasistowskiego ideologa, podkreślając, że politykę internowania Żydów i ich deportacji do obozów koncentracyjnych zaczęto realizować na mocy dekretu ministra spraw wewnętrznych Guida Buffarini Guidiego z 30 listopada 1943 r., a więc jeszcze przed powrotem Preziosiego do Włoch, natomiast w kwestii polityki rasistowskiej obowiązywał program przyjęty na kongresie w Weronie, który wprowadzif dodatkowe zaostrzenia w stosunku do ustaw z 1938 r. ${ }^{66}$ Wobec wyraźnej niechęci faszystowskiego duce i ministra Buffarini Guidiego w stosunku do nadgorliwego inspektora do spraw rasy, zasięg jego oddziaływania był bardzo ograniczony, o czym świadczy dobitnie fakt, że opracowane przez niego dekrety z 15 maja 1944 r., wzorowane na norymberskich ustawach rasowych, nie zostały wprowadzone w życie. Dużo większą rolę Preziosi odegrał jako jeden z naczelnych ideologów włoskiego antysemityzmu XX w. oraz redaktor głównego pisma o charakterze rasistowskim „La Vita Italiana”, które ukazywało się aż do lutego 1945 r. Nie ulega wątpliwości, że w tym właśnie charakterze przyczynił się on nie tylko do opracowania podstaw ideologicznych usprawiedliwiających politykę rasistowską już w 1938 r., ale także do radykalizacji nastrojów antyżydowskich faszyzmu republikańskiego.

65 Zob.: R. De Felice, Storia degli ebrei..., s. 444.

66 Zob.: S. Zuccotti, L'Olocausto in Italia, Milano 1988, s. 191. 


\section{BIBLIOGRAFIA}

\section{Cytowane dzieła Giovanniego Preziosiego}

Giudaismo, bolscevismo, plutocrazia, massoneria, Milano 1943.

Gli Italiani negli Stati Uniti del Nord, Milano 1909.

I Protocolli dei Savi Anziani di Sion, con introduzione e appendice di G. Preziosi, Milano 1944.

La Germania alla conquista dell'Italia, Firenze 1915.

\section{Monografie i artykuły}

Badoglio P., L'Italia durante la seconda guerra mondiale, Milano 1946.

Caffaz U., L'antisemitismo italiano sotto il fascismo, Firenze 1975.

Canaveri E., Come morirono. G. Preziosi, „Meridiano d'Italia” 1959, t. 14, nr 65.

Canepa A.M., Half-hearted cynicism. Mussolini's racial politics, „Patterns of Prejudice” 1979, nr 13(6), [online] http://dx.doi.org/10.1080/0031322X.1979.9969540.

De Felice R., Mussolini il rivoluzionario, Torino 2005.

De Felice R., Storia degli ebrei italiani sotto il fascismo, Torino 1961.

Giovanni Preziosi e la questione della razza in Italia. Atti del Convegno di studi (Avellino-Torela dei Lombardi, 30 novembre - 2 dicembre 2000), a cura di L. Parente, F. Gentile, R.M. Grillo, Soveria Mannelli 2005.

Il fascismo e le autonomie locali, a cura di S. Fontana, Bologna 1973.

Kirkpatrick I., Mussolini. Study of a Demagogue, London 1964.

Kluke P., Gutachten des Instituts für Zeitgeschichte, t. 2, Stuttgart 1966.

Kozub-Ciembroniewicz W., Doktryny wtoskiego faszyzmu i antyfaszyzmu w latach 1922-1939, Kraków 1992, Zeszyty Naukowe Uniwersytetu Jagiellońskiego, 1068, Prace z Nauk Politycznych, z. 45.

Kozub-Ciembroniewicz W., Żydzi w doktrynie wtoskiego faszyzmu na tle Manifesto degli scienziati razzisti z 14 lipca 1938 r. , Studia nad Faszyzmem i Zbrodniami Hitlerowskimi” 1992, t. 15.

La Repubblica Sociale Italiana a Desenzano. Giovanni Preziosi el'Ispettorato generale per la raz$z a$, a cura di M. Sarfatti, Firenze 2008.

Ledeen M.A., La "Questione ebraica” nell'Italia fascista, „Nuova Antologia” 1974, nr 109.

Ludwig E., Colloqui con Mussolini, trad. T. Gnoli, Mondadori, Milano 1932.

Mayda G., Ebrei sotto Salo, Milano 1978.

Michaelis M., On the Jewish question in Fascist Italy. The Attitude of the Fascist Regime to the Jews in Italy, ,Yad Vashem Studies” 1960, nr 4.

Michaelis M., Riflessioni sulla recente storia dell'Ebraismo italiano, „Rassegna mensile d'Israel” 1977 , t. 43, nr 5-6.

Momigliano E., Storia tragica e grottesca del razzismo fascista, Milano 1946.

Monari D., Il miglioramento della razza e il Fascismo, "Gerarchia” 1922, nr 9.

Pentad [Fano P.P., Magri A.F., Minio Paluello L., Orlando R., Thomas I.], The remaking of Italy, London 1941.

Pichetto M.T., Alle radici dell’odio. Preziosi e Benigni antisemiti, Milano 1983. 
Pommerin R., Le controversie di politica razziale nei rapporti dell'Asse Roma-Berlino (1938-1943), „Storia Contemporanea” 1979, nr 4-5.

Pyciński S., Matżeństwa „mieszane” w faszystowskich Wtoszech (1938-1945), „Studia nad Faszyzmem i Zbrodniami Hitlerowskimi” 2002, t. 25.

Rossi G.S., Mussolini e il diplomatico, Soveria Mannelli 2005.

Salvatorelli L., Mira G., Storia d'Italia nel periodo fascista, Torino 1957.

Sarfatti M., La Shoah in Italia. La persecuzione degli ebrei sotto il fascismo, Torino 2005.

Zuccotti S., L'Olocausto in Italia, Milano 1988.

Dr Joanna SONDEL-CEDARMAS - adiunkt w Instytucie Europeistyki UJ. Zajmuje się współczesną włoską myślą polityczną oraz polsko-włoskimi relacjami kulturalnymi na przełomie XIX i XX w. Tej tematyce poświęciła monografię pt. Gabriele D’Annunzio. U źródet ideologicznych wtoskiego faszyzmu (Kraków 2008) oraz szereg artykułów opublikowanych m.in. na łamach "Studiów nad Faszyzmem i Zbrodniami Hitlerowskimi”, „Politei”, „Czasopisma Historyczno-Prawnego” oraz „Romanica Cracoviensia”. Jest członkiem Istituto per la storia del Risorgimento Italiano w Rzymie. 